\title{
Influence of Co Precursor and Pt Additive on Catalytic Performance of Highly Active $\mathrm{Co} / \mathrm{SiO}_{2}$-based Fischer-Tropsch Synthesis Catalysts
}

\author{
Noriyuki YAMANE ${ }^{*}{ }^{* 2}$, Kimihito SUZUKI ${ }^{* 2}$, Minghui TAN ${ }^{* 1}$, and Noritatsu TSUBAKI ${ }^{*}{ }^{\dagger}$ \\ (Received March 15, 2017)
}

The effect of Co precursor and $\mathrm{Pt}$ additive on catalytic activity was investigated for $\mathrm{Co} / \mathrm{SiO}_{2}$ catalysts used for Fischer-Tropsch (FT) synthesis. FT reaction activity of $\mathrm{Co} / \mathrm{SiO}_{2}$ prepared using $\mathrm{Co}$ acetate as Co precursor was not high, but it was improved notably by adding small amount of Pt. It was found that small Co particles, which were hard to be reduced, were formed in the catalyst prepared using Co acetate. It is believed that the enhanced activity by Pt additive was mainly attributed to the improved reduction of small Co particles due to the added Pt. In addition, although the activity of $\mathrm{Pt}-\mathrm{Co} / \mathrm{SiO}_{2}$ prepared using $\mathrm{Co}$ acetate as precursor was extremely high, but the selectivity of $\mathrm{C}_{5+}$ hydrocarbons was relatively low because of smaller Co particle size, and consequently there was no much difference on $\mathrm{C}_{5+}$ hydrocarbons productivity when the Co precursor was varied.

不純物含有量が少ない $\mathrm{SiO}_{2}$ 担体に Co を $30 \mathrm{wt} \%$ 担持した高活性触媒について, Co 前駆体の影響, Pt 助触媒の効果を評 価したところ, 酢酸コバルトを前駆体として調製した $\mathrm{Co} / \mathrm{SiO}_{2}$ 触媒の活性は高くないが, $\mathrm{Pt}$ 助触媒を少量添加することで活性は飛 躍的に向上した。Pt 助触媒の添加による活性向上は, 還元されにくい小粒子径 Co が還元されたためと考えられる。しかし, 酢酸 コバルトを前駆体として調製した $\mathrm{Pt}-\mathrm{Co} / \mathrm{SiO}_{2}$ 触媒の活性は著しく高いものの, $\mathrm{C}_{5+}$ 選択率は相対的に高くなく, $\mathrm{C}_{5+}$ 生産性は $\mathrm{Co}$ 前 駆体によって大きな差は見られなかった。

\section{Key Words}

Fischer-Tropsch synthesis, Cobalt catalyst, Precursor, Pt addition, Gas-To-Liquid

\section{Introduction}

FT synthesis reaction is a synthesis method to produce clean liquid fuel from a mixed gas of carbon monoxide and hydrogen. Like the large-scale development technology in natural gas field in Qatar, etc., some commercial plants of GTL (Gas to Liquids) using Co-based FT catalyst are now operated ${ }^{1)}$.

On the preparation of Co-based FT catalysts in industrial process, porous inorganic compounds such as $\mathrm{Al}_{2} \mathrm{O}_{3}, \mathrm{SiO}_{2}, \mathrm{TiO}_{2}$, etc. were always adopted as catalyst support and the catalyst was prepared by impregnation methods like incipient wetness, etc.. Catalyst activity of Cobased FT catalyst mainly depends on the loading amount of Co, additives, and content of alkaline metal or alkaline earth

\footnotetext{
※1 Department of Applied Chemistry, School of Engineering, University of Toyama Gofuku 3190, Toyama 930-8555, Japan

※2 Advanced Technology Research Laboratories, Nippon Steel \& Sumitomo Metal Corporation 20-1 Shintomi, Futtsu-shi, Chiba 293-8511, Japan

$\dagger \quad$ Corresponding author: tsubaki@eng.u-toyama.ac.jp
}

metal which were inevitable impurities during catalyst production. It was reported that highly active catalyst could be obtained by lowering these impurities amount below around $100 \mathrm{ppm}^{2}$. The structure and chemical state of active Co metal particles on the catalyst could greatly influence the catalytic activity ${ }^{3)}$.

It is a huge advantage in reducing the catalyst cost by using highly active catalyst, because it can decrease the loaded amount of catalyst for commercial plant. In this study, influence of Co precursor and $\mathrm{Pt}$ additive on the catalytic activity of highly active $\mathrm{Co} / \mathrm{SiO}_{2}$-based catalysts with 30 wt\% Co loading employing high-purity $\mathrm{SiO}_{2}$ support was investigated, aiming at the application to a commercial GTL plant.

\section{Experimental}

\subsection{Catalysts preparation}

Catalysts were prepared by incipient wetness impregnation using $\mathrm{Co}$ nitrate $\left(\mathrm{Co}\left(\mathrm{NO}_{3}\right)_{2} \cdot 6 \mathrm{H}_{2} \mathrm{O}\right)$ or $\mathrm{Co}$ acetate $\left(\mathrm{Co}\left(\mathrm{CH}_{3} \mathrm{COO}\right)_{2} \cdot 4 \mathrm{H}_{2} \mathrm{O}\right)$ as Co precursor. $30 \mathrm{wt} \%$ of $\mathrm{Co}$ 
was loaded on pure $\mathrm{SiO}_{2}$ support containing Na: 105 ppm, Ca: 131 ppm, Mg: 4 ppm. As the adopted SV (space velocity) was rather high $(\mathrm{W} / \mathrm{F}=1.5 \mathrm{gh} / \mathrm{mol})$, to achieve high $\mathrm{CO}$ conversion and high productivity, enhanced Co loading such as $30 \mathrm{wt} \%$ here was necessary. Drying treatment (393 K for $1 \mathrm{~h}$ ) and calcination treatment (673 K for $5 \mathrm{~h}$ ) were performed successively after Co loading. In the case of $\mathrm{Pt}$ addition, $0.1 \mathrm{wt} \%$ of $\mathrm{Pt}$ was loaded on $\mathrm{Co} / \mathrm{SiO}_{2}$ by incipient wetness impregnation using $\mathrm{H}_{2} \mathrm{PtCl}_{6}$ aqueous solution, and then drying and calcination were carried out. Reduction was performed in hydrogen flow at $673 \mathrm{~K}$ for $15 \mathrm{~h}$ and then passivation was carried out in $1 \% \mathrm{O}_{2} / \mathrm{Ar}$ balance gas at room temperature for $40 \mathrm{~h}$. The catalyst nomenclatures were listed in Table 1. For example, $\mathrm{Co} / \mathrm{SiO}_{2}$ (Co acetate) meant the catalyst prepared using $\mathrm{Co}\left(\mathrm{CH}_{3} \mathrm{COO}\right)_{2} \cdot 4 \mathrm{H}_{2} \mathrm{O}$ as the cobalt precursor.

\subsection{Reaction of the catalysts}

The reaction of FT synthesis was carried out in an autoclave with an inner volume of $300 \mathrm{~mL} .1 \mathrm{~g}$ of catalyst and $50 \mathrm{ml}$ of n-hexadecane were charged into the autoclave. Thereafter, the flow rate of syngas $\left(\mathrm{H}_{2} / \mathrm{CO} /\right.$ Ar $=60 \% / 30 \% / 10 \%$ ) was adjusted to obtain $\mathrm{W} / \mathrm{F}=1.5 \mathrm{gh} /$ mol, while an agitator was rotated at $800 \mathrm{r} / \mathrm{min}$ under the condition of $503 \mathrm{~K}$ and $2.2 \mathrm{MPa}$. The composition of autoclave outlet gas was analyzed by gas chromatography equipped with a thermal conductivity detector (TCD) and a flame ionization detector (FID). CO conversion, product selectivity, and $\mathrm{C}_{5+}$ productivity were calculated using the average value from 16 to 20 hour after reaction started.

\subsection{Catalyst characterization}

Reduction degree was measured by oxygen adsorption using Quantachrome AUTOSORB-1 gas sorption analyzer.

Table 1 Nomenclature of catalysts

\begin{tabular}{cc}
\hline Catalyst & Co precursor \\
\hline $\mathrm{Pt}-\mathrm{Co} / \mathrm{SiO}_{2}$ (Co acetate) & $\mathrm{Co}\left(\mathrm{CH}_{3} \mathrm{COO}\right)_{2} \cdot 4 \mathrm{H}_{2} \mathrm{O}$ \\
$\mathrm{Co} / \mathrm{SiO}_{2}$ (Co acetate) & $\mathrm{Co}\left(\mathrm{CH}_{3} \mathrm{COO}\right)_{2} \cdot 4 \mathrm{H}_{2} \mathrm{O}$ \\
$\mathrm{Pt}-\mathrm{Co} / \mathrm{SiO}_{2}$ (Co nitrate) & $\mathrm{Co}\left(\mathrm{NO}_{3}\right)_{2} \cdot 6 \mathrm{H}_{2} \mathrm{O}$ \\
$\mathrm{Co} / \mathrm{SiO}_{2}$ (Co nitrate) & $\mathrm{Co}\left(\mathrm{NO}_{3}\right)_{2} \cdot 6 \mathrm{H}_{2} \mathrm{O}$ \\
\hline
\end{tabular}

Prior to analysis, catalysts were reduced by hydrogen at $673 \mathrm{~K}$ for $1 \mathrm{~h} . \mathrm{H}_{2}$-TPR (Temperature-programmed reduction) was conducted on BELCAT II equipment. Samples of $0.1 \mathrm{~g}$ without reduction treatment were charged into the equipment and then pretreatment (673 K for $0.5 \mathrm{~h}$ ) was carried out under argon gas flow. After cooling to room temperature, temperature was elevated from room temperature to $1142 \mathrm{~K}$ with a temperature ramp rate of $1 \mathrm{~K} / \mathrm{min}$ under the $5 \% \mathrm{H}_{2} / \mathrm{Ar}$ gas. X-ray diffraction (XRD) was performed employing RINT 1500 (RIGAKU Co. Ltd.) recorded from 5 to $100^{\circ}$ with a scan speed of $1 \%$ min. Transmission electron microscopy (TEM) analysis was carried out using JEM2100F (JEOL Ltd.) equipped with an energy-dispersive spectrometer (JED2300T) under an accelerating voltage of $200 \mathrm{kV}$.

\section{Results and discussion}

FT synthesis reaction performances over $\mathrm{Co} / \mathrm{SiO}_{2}-$ based catalysts were shown in Table 2. $\mathrm{Co} / \mathrm{SiO}_{2}$ (Co acetate) showed lower $\mathrm{CO}$ conversion of $58.8 \%$ than $72.3 \%$ of $\mathrm{Co} / \mathrm{SiO}_{2}$ (Co nitrate), indicating that Co precursor type had great influence on the catalytic activity of $\mathrm{Co} / \mathrm{SiO}_{2}$-based catalyst. $\mathrm{Pt}-\mathrm{Co} / \mathrm{SiO}_{2}$ (Co acetate) showed the highest activity with the $\mathrm{CO}$ conversion of $78.7 \%$, and the highest productivity of 2,365 g/kg-cat.h. Effect of $0.1 \mathrm{wt} \%$ of Pt additive was evaluated as $20 \%$ increase of the CO conversion and 600g/ kg-cat.h improvement of the productivity. On the other hand, the $\mathrm{CO}$ conversion and productivity of $\mathrm{Pt}-\mathrm{Co} / \mathrm{SiO}_{2}$ (Co nitrate) were slightly lower than those of $\mathrm{Pt}-\mathrm{Co} / \mathrm{SiO}_{2}$ (Co acetate), but its $\mathrm{C}_{5+}$ selectivity was higher than that of $\mathrm{Pt}-\mathrm{Co} / \mathrm{SiO}_{2}$ (Co acetate). As the $\mathrm{CO}$ conversion of $\mathrm{Co} / \mathrm{SiO}_{2}$ (Co nitrate) was $72.3 \%$, effect of $\mathrm{Pt}$ additive was estimated as only $2 \%$ increase of CO conversion and $60 \mathrm{~g} / \mathrm{kg}$-cat.h improvement of productivity which was merely one-tenth the case of the catalysts prepared using Co acetate. This result indicated that catalyst activity was improved notably by $\mathrm{Pt}$ additive in the case of the catalyst prepared using Co acetate whereas catalyst activity was high enough without Pt addition in the case of the catalyst prepared using Co nitrate.

Reduction degree and particle size of Co particles on

Table 2 Reaction performance comparison of catalysts

\begin{tabular}{cccccc}
\hline \multirow{2}{*}{ Catalyst } & \multirow{2}{*}{$\mathrm{CO}$ conv. (\%) } & \multicolumn{3}{c}{ Sel. (\%) } & $\begin{array}{c}\text { Productivity } \\
\text { (g/kg-cat.h) }\end{array}$ \\
\cline { 3 - 5 } & & $\mathrm{CH}_{4}$ & $\mathrm{CO}_{2}$ & $\mathrm{C}_{5+}$ & 2,365 \\
$\mathrm{Pt}-\mathrm{Co} / \mathrm{SiO}_{2}$ (Co acetate) & 78.7 & 5.0 & 1.2 & 88.0 & 1,774 \\
$\mathrm{Co} / \mathrm{SiO}_{2}$ (Co acetate) & 58.8 & 6.3 & 0.3 & 87.8 & 2,322 \\
$\mathrm{Pt}-\mathrm{Co} / \mathrm{SiO}_{2}$ (Co nitrate) & 74.0 & 3.8 & 0.5 & 92.2 & 2,263 \\
$\mathrm{Co} / \mathrm{SiO}_{2}$ (Co nitrate) & 72.3 & 3.9 & 0.5 & 91.9 & \\
\hline
\end{tabular}

Reaction conditions: $503 \mathrm{~K}, 2.2 \mathrm{MPa}, \mathrm{W} / \mathrm{F}=1.5 \mathrm{~g} \cdot \mathrm{h} / \mathrm{mol}, \mathrm{H}_{2} / \mathrm{CO}=2$ 
the catalysts were assumed to be the factors determining the catalyst activity since the active site of Co-base FT catalysts was Co metal. Therefore, reduction degree and particle size of Co particles were evaluated by oxygen adsorption, $\mathrm{H}_{2}$-TPR, XRD and TEM respectively.

Table 3 compared the reduction degree of the varied $\mathrm{Co} / \mathrm{SiO}_{2}$ catalysts. Reduction degree of the most active $\mathrm{Pt}-\mathrm{Co} / \mathrm{SiO}_{2}$ (Co acetate) catalyst was not high, $57.9 \%$. However, $\mathrm{Co} / \mathrm{SiO}_{2}$ (Co acetate) without $\mathrm{Pt}$ showed lowest reduction degree of 33.0\%. 25\% improvement was estimated for reduction degree of Co particles by addition of $\mathrm{Pt}$ on catalyst surface. On the other hand, compared with $\mathrm{Co} / \mathrm{SiO}_{2}$ (Co acetate), $\mathrm{Co} / \mathrm{SiO}_{2}$ (Co nitrate) showed a high reduction degree of $93.9 \%$ and enhanced slightly to 96.8\% by $\mathrm{Pt}$ addition. Enhancement effect of reduction degree by $\mathrm{Pt}$ additive for $\mathrm{Pt}-\mathrm{Co} / \mathrm{SiO}_{2}$ (Co nitrate) was only $3 \%$. There is a good correlation between the improvement of reduction degree and the enhancement of activity by $\mathrm{Pt}$ additive. $\mathrm{Pt}-\mathrm{Co} / \mathrm{SiO}_{2}$ (Co acetate) showed highest activity even if reduction degree of $\mathrm{Pt}-\mathrm{Co} / \mathrm{SiO}_{2}$ (Co acetate) was low, compared with $\mathrm{Pt}-\mathrm{Co} / \mathrm{SiO}_{2}$ (Co nitrate) and $\mathrm{Co} / \mathrm{SiO}_{2}(\mathrm{Co}$ nitrate). It is considered that the surface area of Co metal in $\mathrm{Pt}-\mathrm{Co} / \mathrm{SiO}_{2}$ (Co acetate) was higher than that of other catalysts because much small Co particles were formed as mentioned below.

To clarify the reason why the reduction degree of the catalysts prepared using Co acetate was low. TPR of these catalysts was conducted. The TPR profiles of the catalysts were given in Fig. 1. These profiles varied for catalysts prepared with different $\mathrm{Co}$ precursor. $\mathrm{Co} / \mathrm{SiO}_{2}(\mathrm{Co}$

Table 3 Reduction degree of catalysts

\begin{tabular}{cc}
\hline Catalyst & Reduction degree $(\%)$ \\
\hline $\mathrm{Pt}-\mathrm{Co} / \mathrm{SiO}_{2}$ (Co acetate) & 57.9 \\
$\mathrm{Co} / \mathrm{SiO}_{2}$ (Co acetate) & 33.0 \\
$\mathrm{Pt}-\mathrm{Co} / \mathrm{SiO}_{2}$ (Co nitrate) & 96.8 \\
$\mathrm{Co} / \mathrm{SiO}_{2}$ (Co nitrate) & 93.9 \\
\hline
\end{tabular}

acetate) exhibited the peak of reduction at $1055 \mathrm{~K}$. After addition of $\mathrm{Pt}$, peaks shifted to low temperature in both catalysts prepared using different Co precursors and the shift of peak was larger in the catalyst prepared using Co acetate specifically. Furthermore, the reduction temperature of $\mathrm{Pt}-\mathrm{Co} / \mathrm{SiO}_{2}$ (Co acetate) was higher than that of $\mathrm{Pt}-\mathrm{Co} /$ $\mathrm{SiO}_{2}$ (Co nitrate). This means that Co particles of $\mathrm{Pt}-\mathrm{Co} / \mathrm{SiO}_{2}$ (Co acetate) were difficult to be reduced in reduction process compared with the catalysts prepared using Co nitrate.

In order to investigate the structure of these catalysts after reduction, XRD was conducted. XRD patterns of the catalysts were depicted in Fig. 2. In the catalysts prepared using Co acetate, clear peaks of Co metal were not found. It was found that the peaks ascribed to $\mathrm{CoO}$ diminished and the peak width of $2 \theta$ value from $42^{\circ}$ to $45^{\circ}$ grew to wideangle by $\mathrm{Pt}$ addition. It indicated that reducing character of Co particles increased and the peak around $44.5^{\circ}$ ascribed to Co metal appeared by addition of Pt. This result was accorded with the findings of oxygen adsorption and TPR. The estimation from the broadening of diffraction peaks at $42.7^{\circ}$ according to Scherrer's equation gave crystallite size of $5.2 \mathrm{~nm}$ for $\mathrm{CoO}$ in $\mathrm{Co} / \mathrm{SiO}_{2}$ (Co acetate). In Pt-Co/ $\mathrm{SiO}_{2}$ (Co acetate), it was impossible to evaluate the crystallite size since there existed no independent peaks of $\mathrm{Co}$ metal, $\mathrm{CoO}$, or $\mathrm{Co}_{3} \mathrm{O}_{4}$. On the other hand, a sharp peak appeared in the case of the catalysts prepared using Co nitrate. Crystallite size for Co metal was $14.5 \mathrm{~nm}$ for $\mathrm{Pt}-\mathrm{Co} / \mathrm{SiO}_{2}$ (Co nitrate), $14.0 \mathrm{~nm}$ for $\mathrm{Co} / \mathrm{SiO}_{2}$ (Co nitrate), respectively. Compared with the catalyst prepared using Co acetate, Co particle size was almost triple in the catalysts prepared using Co nitrate. Fig. 3 compares the TEM images of $\mathrm{Pt}-\mathrm{Co} / \mathrm{SiO}_{2}$ (Co acetate) and $\mathrm{Pt}-\mathrm{Co} / \mathrm{SiO}_{2}$ (Co nitrate). The TEM images demonstrate that small Co particles are dispersed well in $\mathrm{Pt}-\mathrm{Co} / \mathrm{SiO}_{2}(\mathrm{Co}$ acetate), while larger $\mathrm{Co}$ particles form aggregate in $\mathrm{Pt}-\mathrm{Co} /$ $\mathrm{SiO}_{2}$ (Co nitrate). Fig. 4 demonstrates the EDS mapping of TEM image for $\mathrm{Pt}-\mathrm{Co} / \mathrm{SiO}_{2}$ (Co nitrate) in order to elucidate the position between $\mathrm{Pt}$ and $\mathrm{Co}$ on the silica support.

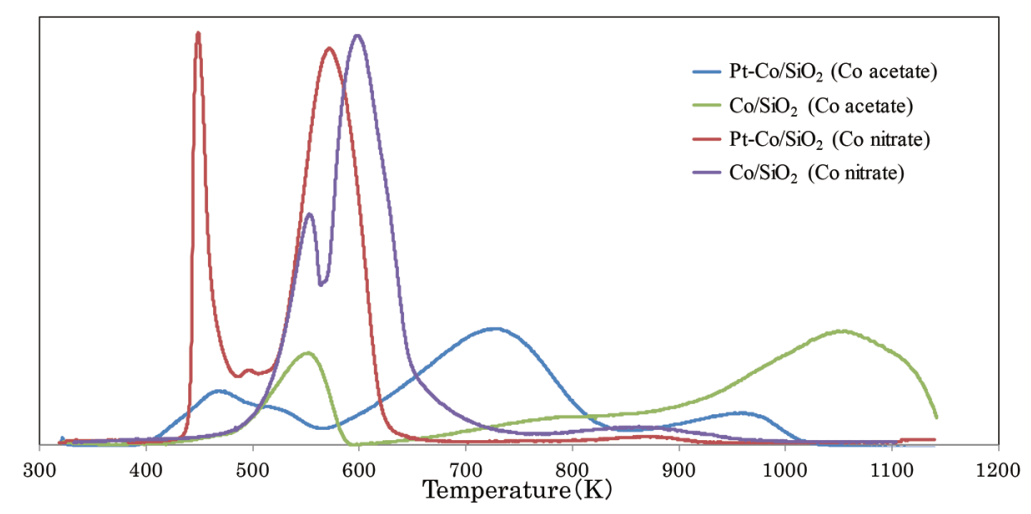

Fig. 1 TPR profiles of catalysts $\left(5 \% / \mathrm{H}_{2} / \mathrm{Ar}\right.$, Ramp rate: $\left.1 \mathrm{~K} / \mathrm{min}\right)$ 


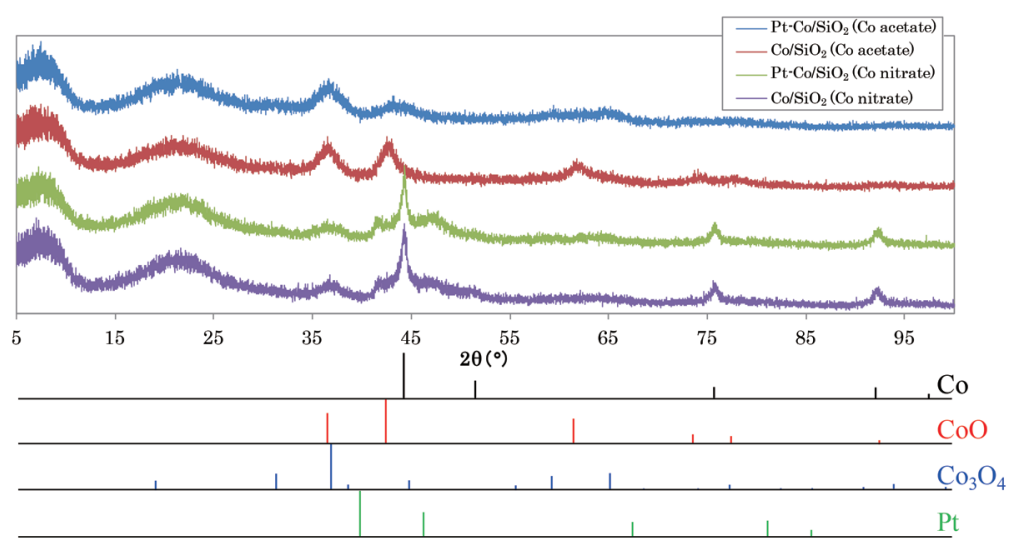

Fig. 2 X-ray diffraction patterns of catalysts
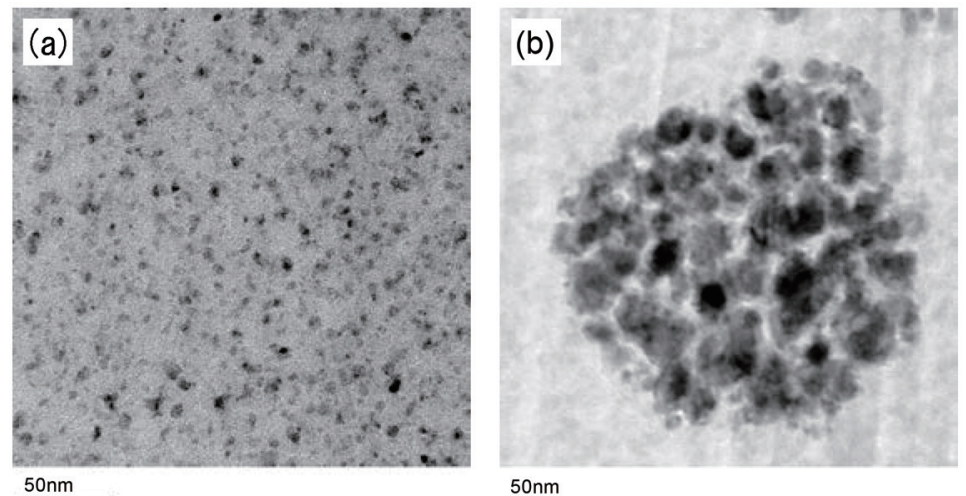

Fig. 3 TEM images of $\mathrm{Pt}-\mathrm{Co} / \mathrm{SiO}_{2}$ (Co acetate): (a), and $\mathrm{Pt}-\mathrm{Co} / \mathrm{SiO}_{2}$ (Co nitrate): (b)

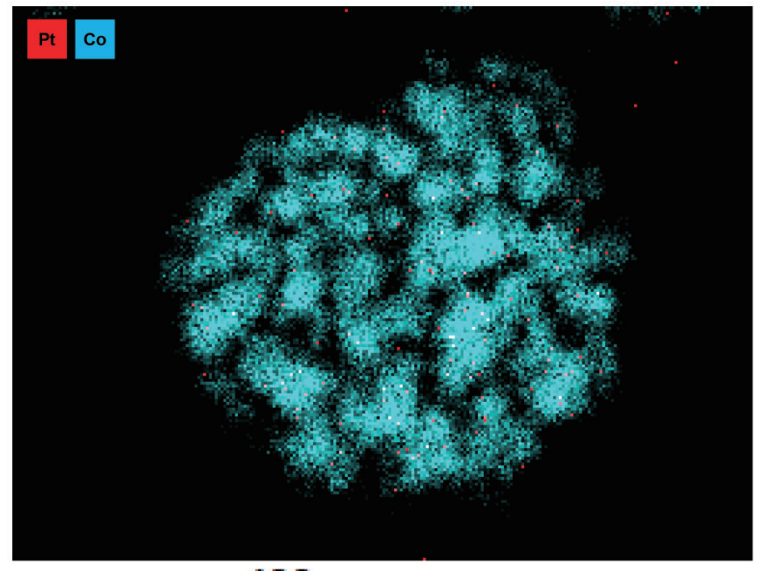

$100 \mathrm{~nm}$

Fig. 4 EDS mapping of TEM image for $\mathrm{Pt}-\mathrm{Co} / \mathrm{SiO}_{2}$ (Co nitrate)

Small amount of Pt existed on the location of Co particles, though Pt was barely detected in whole image. This finding discloses that Pt particles were contacted with Co particles. This Co particle size difference determined different $\mathrm{C}_{5+}$ hydrocarbon selectivity as listed in Table 2 . It is reported that carbon chain growth probability was enhanced on larger Co particle size in FT synthesis ${ }^{4)}$. It is considered that readsorption of $\alpha$-olefins was promoted on larger Co particle. Consequently Co-based FT synthesis catalysts derived from nitrate precursor, with larger metallic cobalt crystallite sizes, exhibited higher $\mathrm{C}_{5+}$ hydrocarbon selectivity.

Being linked to carbon chain growth probability and $\mathrm{C}_{5+}$ hydrocarbon selectivity, Co particle size variation could be controlled by the interaction between Co precursor solution and catalyst support. Sintering of Co particles was unfavorable during drying, calcination and reduction processes after impregnation. If the interaction between Co precursor solution and catalyst support was strong, small Co particles would be formed. However, fine Co particles were hard to be reduced since these particles interacted with catalyst support strongly. One effective methodology to boost up the reduction degree of these fine cobalt oxide particles was implanting the co-existing noble metals such as $\mathrm{Pt}, \mathrm{Pd}$, to facilitate the $\mathrm{H}_{2}$ spillover by these co-existing noble metals from syngas, quickly reducing the neighboring cobalt oxide species ${ }^{5}$.

\section{Conclusions}

The effect of Co precursor and $\mathrm{Pt}$ additive on catalytic performance was investigated for FT synthesis 
reaction over highly active catalyst, which loaded Co of 30 wt\% on $\mathrm{SiO}_{2}$ support containing low impurities. The catalysts using different Co precursors exhibited varied catalytic activity and $\mathrm{Pt}$ additive also had different influence on the activity of both catalysts. FT reaction activity of $\mathrm{Co} / \mathrm{SiO}_{2}$ prepared using $\mathrm{Co}$ acetate as Co precursor was not high, but it could be improved notably by adding a small amount of Pt. On the other hand, the activity of $\mathrm{Co}$ / $\mathrm{SiO}_{2}$ prepared using Co nitrate was high even though the catalyst did not involve $\mathrm{Pt}$, and the effect of Pt additive on this catalyst was negligible. It was found that much more small Co particles which were difficult to be reduced were formed on $\mathrm{Co} / \mathrm{SiO}_{2}$ (Co acetate). It is believed that $\mathrm{Pt}$ addition could facilitate the reduction of these small Co particles, hence improved the activity obviously. In addition, although the activity of $\mathrm{Pt}-\mathrm{Co} / \mathrm{SiO}_{2}$ prepared using $\mathrm{Co}$ acetate as precursor was extremely high, but the selectivity of $\mathrm{C}_{5+}$ hydrocarbons was relatively low, and there was no much difference on $\mathrm{C}_{5+}$ productivity when the Co precursor was different.

\section{References}

1) Muroi, T., Petrotech, 36, 70-75 (2013)

2) U.S. patent 2012289615(A1)

3) Rosynek, M. P.; Polansky, C. A., Applied Catalysis, 73, 97$112(1991)$

4) Xing, C.; Ai, P.; Zhang, P.; Gao, X.; Yang, R.; Yamane, N.; Sun, J.; Prasert, R.; Tsubaki, N., Journal of Energy Chemistry, 25, 994-1000 (2016)

5) Lin, Q.; Zhang, Q.; Yang, G.; Chen, Q.; Li, J.; Wei, Q.; Tan, Y.; Wan, H.; Tsubaki, N., Journal of Catalysis, 344, 378388 (2016) 